doi $10.15826 /$ recon.2018.4.4.018

\title{
Lifelong learning as a tool for the development of smart cities: technology enhanced learning as an enabler
}

\author{
Ken Brown ${ }^{a}$, Viola A. Larionova ${ }^{b}$, Vic Lally ${ }^{c}$ \\ a Letterkenny Institute of Technology, Letterkenny, Ireland; e-mail: ken.brown@lyit.ie \\ ${ }^{b}$ Ural Federal University, Ekaterinburg, Russia; e-mail: viola-larionova@yandex.ru \\ c University of Glasgow, Glasgow, United Kingdom; e-mail:vic@viclally.co.uk
}

\begin{abstract}
This paper considers the ubiquity of technology as an enabler for lifelong learning in modern society and the impact this dependence on technology has on the strategic design of learning systems. The role of lifelong learning in modern economies and the diversity of activities associated with lifelong learning requires targeted resourcing and understanding of the meaning of lifelong learning. The dominance of technology enhanced learning in modern education is accepted as a de-facto component in the design of any learning programme. The literature on the technology enhanced learning - smart city nexus explores the technology in depth with a strong focus on learning analytics and big data applications. Evidence of the pedagogical paradigm requirements is not quite so visible and this lack of understanding of the complete model creates tensions in the design of lifelong learning systems. The agency of active learning is considered in the sense of the triune of human, education and economic, systems for the sustainable growth of a knowledge economy. Structured approaches to learning are demonstrated and comparison is drawn with smart city projects in Ireland and the United Kingdom.
\end{abstract}

\section{KEYWORDS}

lifelong learning, technology enhanced learning, smart cities, e-learning, smart learning, massively open online courses, Russia, Ireland, United Kingdom

\section{ACKNOWLEDGEMENTS}

The authors would like to express their deepest gratitude to the Russian Foundation for Basic Research (RFBR) for the support of the research within the project No. 17-22-07001

The Complex Algorithm of Culture-Based Regeneration of Minor Industrial Cities in the Context of Agglomeration Processes in Russia and Europe.

\section{FOR CITATION}

Brown, K., Larionova, V. A., Lally, V. (2018) Lifelong learning as a tool for the development of smart cities: technology enhanced learning as an enabler. R-economy, 4(4), 133-143. doi: 10.15826/recon.2018.4.4.018

\section{Непрерывное обучение в качестве инструмента для развития умных городов: технологии, способствующие обучению}

\author{
К. Браун ${ }^{a}$, В. А. Ларионова ${ }^{b}$, В. Лэлли ${ }^{c}$ \\ ${ }^{a}$ Институт технологий Леттеркенни, Леттеркенни, Ирландия; e-mail: ken.brown@lyit.ie \\ ${ }^{b}$ Уральский федеральньй университет, Екатеринбург, Pоссия; e-mail: viola-larionova@yandex.ru \\ ' Университет Глазго, Глазго, Великобритания; e-mail: vic@viclally.co.uk
}

\begin{abstract}
АННОТАЦИЯ
В статье рассматривается повсеместное распространение технологий в качестве инструмента для непрерывного обучения в современном обществе, а также влияние их связи на технологии для стратегического проектирования систем обучения. Роль непрерывного обучения в современной экономике и разнообразие видов деятельности, связанных с ним, требуют целенаправленного выделения ресурсов и понимания смысла непрерывного обучения. Доминирование технологии улучшенного обучения в современном образовании признается де-факто компонентом в разработке любой учебной программы. Литература о технологиях, развивающих взаимосвязь между обучением и умным городом, подробно исследует эту технологию, уделяя особое внимание обучающей аналитике и приложениям для работы с большими данными. Доказательства требований педагогической парадигмы не так очевидны, и это непонимание полной модели создает напряженность в разработке систем непрерывного обучения. Учреждение активного обучения рассматривается в смысле триединства человека, образования и экономики, систем устойчивого роста экономики знаний. Показаны структурированные подходы к обучению и проведено сравнение с проектами «умный город» в Ирландии и Великобритании.
\end{abstract}

\section{КЛЮЧЕВЫЕ СЛОВА}

непрерывное обучение, технология улучшенного обучения, умные города, электронное обучение, умное обучение, массово открытые онлайн-курсы, Россия, Ирландия, Великобритания

\section{БЛАГОДАРНОСТИ}

Авторы выражают глубокую благодарность Российскому фонду фундаментальных исследований (РФФИ) за поддержку исследований в рамках проекта

№ 17-22-07001 «Комплексный алгоритм культурной регенерации малых промышленных городов в контексте агломерационных процессов в России и Европе»

\section{ДЛЯ ЦИТИРОВАНИЯ}

Brown, K., Larionova, V. A., Lally, V. (2018) Lifelong learning as a tool for the development of smart cities: technology enhanced learning as an enabler. R-economy, 4(4), 133-143. doi: 10.15826/recon.2018.4.4.018 


\section{Introduction}

The role of technology is accepted as a central tenet in modern society and this acceptance is visible in the use of technology for learning at all levels of education. Education in modern society is inextricably linked to the highly complex ecosystem of the national economy and is considered to be a fundamental component of the smart city [1]. A smart city should support learning and be supported by learning within the agencies of economy, environment, governance, living, mobility, and people [2]. Integration of all factors to support the smart city requires education, and in particular, a highly integrated university-city nexus.

The context for the smart city phenomenon is the growth in the percentage of urban population. The urban population is expected to increase globally to 70 percent by 2050 [3]. In Europe, the population is expected to increase to 80 percent by 2020 , whilst the population living in urban areas of Russia is currently 75 percent. The growing importance of cities is recognised globally, and the associated anthropological development requires an appropriate paradigm to address the needs of urban societies to ensure sustainability [4] as cities adapt to the needs of their inhabitants. An issue of concern in research, design and development of an appropriate paradigm for lifelong learning in a smart city is the lack of consensus amongst urban policy makers as to what actually constitutes a smart city $[2 ; 3 ; 5 ; 6]$.

The paradigm for any socio-learning nexus requires an understanding of the needs, purpose and aims of the learning within the context of the society in which it occurs. Anthropological evolution in terms of learning has experienced quantum leaps since the industrial revolution, requiring creativity to maintain learning relevance associated with and within society. The definition of "smart city" by Kominos, cited in [7, p. 29], includes digitally qualified workforce but makes no reference to how less qualified members of society may participate in a meaningful manner. The rich eco-system of the modern smart city has evolved beyond territories with high-capacity for learning and innovation. Gianni and Divitni [7] focus on smart cities as places where citizens learn smart behaviours, with active students engaging in the learning process and where every citizen can be involved. The mapping process [7] considered the social and urban perspectives of the smart city within the fixed domain of the city as an urban space, but it does not consider the widening of access to extend beyond fixed communities of learners.

The lifelong learning process implies active engagement of living within the city and generating knowledge; the traditional nexus of learning within a fixed community is a considerable bond. Modern discourse in relation to the paradigm of learning focuses on the connectivist [8] elements of technology enhanced learning, but does not address the desire for the technology to generate an additive component [9] to the learning process. In this discourse, the emphasis is placed firmly on the technology with little or no emphasis on the learner, thus, the derogation of the role of learning within the technology enhanced paradigm produces a lens on the technology instead of an active agency of the learner. The technology focus sidesteps issues of institutional pressure to conform through the use of technologies. When Skinner [10] developed the behaviourist "teaching machine", his work complemented the theories developed by Weiner \& Shannon [11] to produce a foundation for technology enhanced learning. However, Weiner \& Shannon debated robustly to maintain that the learner should be the central agent within the learning communication processes. The critique of learning in a technology enabled environment focuses largely on the hardware and software for communication but does not consider the one which is developed for pedagogical purposes. Goodwin \& Speed [9] refer to digital cognoscenti in relation to the hegemony of the technology without defining the meaning of this term, but sufficient nuances are place-marked to lead to the conclusion that the technology is deemed to dominate the learner.

The hegemony of technology enhanced learning in the Global North [12] and the tensions created when considering the design implications for meaningful learning within the lifelong learning process are complex and distributed within a wider socio-economic-historical framework. The tensions and problems to be addressed within the smart city learning conundrum present new challenges for educational designers at all levels of the education system. At the macro level, national and international policy makers require knowledge of the paradigm and the tensors affecting the paradigm. The meso level of the region addressed by the strategic approaches of the universities is heavily dependent on the policy decisions of the government, leading to governance of the actions of educational designers at the micro level. The 
smart city should be cognizant of the tensions, actors, processes and products, when reliance is placed heavily on poorly defined constructs.

The definition of the smart city requires a fundamental understanding of all components within the design of the supporting framework. The model presented by Hammad \& Ludlow [8, p. 188] creates a demarcation between the city model and the smart learning environment. The learning separation in this context does not suggest full integration of learning within the smart city model and reduces the voice and presence [13] of the learner as an active agent; the expectation of digital competence and strong self-regulatory skills creates a mask for designers to hide behind. Encapsulation of learning within the smart city context requires data for evidence, analysis, and support of all activities. Greater integration of data - mindful of ethical considerations - offers potential for targeted, mobile and flexible learning. The personal, civic, professional and social skills of the learner may be optimised through appropriate analysis and support. Mobility and flexibility of learning may be achieved through adaptable learning spaces using the artefacts of technology enhanced learning to support adaptable spatial and temporal design processes $[14 ; 15]$.

Learning is a holistic process and the nexus with the complex ecosystem [8] of the smart city requires a holistic paradigm. Inter- and intra-connectivity is vital to ensure that all agents are supported by the artefacts of technology enhanced learning. The holistic support of lifelong learning within a sustainable smart city model is fundamental to the growth of the city, society and the learner.

Widening of access beyond the traditional fixed community of learning has been made possible by developments in education around the concept of open e-learning [16] in the form of the Massively Open Online Course (MOOC). MOOCs appear in the form of learning available to all and support the concept of lifelong learning where opportunities are made available to learners throughout their life. The market created by MOOCs and the benefits received globally by learners and providers cannot be understated even in the face of the cynicism offered by some [17]. The MOOC model is an evolution of the traditional model where materials are developed by experts to satisfy the demand by employers such as universities or private companies. Greater participation with potential for inclusion and diversi- ty is required to ensure that less optimised learners do not suffer from unequal access to resources $[18 ; 19]$. An adaptation of the MOOC in the form of the Connected Learning MOOC [20] offers potential for technology enhanced learning to support the production of digital artefacts through learning with and from other learners in a true community of practice [21]. The CLMOOC has demonstrated that it is possible for true flexibility of lifelong learning to occur outside the traditional school-university context.

The potential to re-order and re-imagine the lifelong learning paradigm using technology as an enabling mechanism is acknowledged in the following question: "How can online education... help less privileged people to learn and/or gain an acknowledged education?" [18].

This question can be addressed by examining the gaps between the open online education systems and the traditional university model. The study requires exploration of lifelong learning education model policies, practices and procedures. The gap may be bridged through the following: knowledge of active and passive agents within the education system; factors affecting resilience and motivation of high achievers as well as those who may also be low achievers; determination of meaningful quality criteria for methodological design of pedagogically sound and technology enabled paradigms for lifelong learning. It is not possible to address all the issues affecting lifelong learning as enabled through technology within a single study, however it is possible to place a lens on salient issues for generation of in-depth discourse. This paper addresses the key issues of socio-learning, motivation and belonging in the light of inclusion processes in an Open Learning society. Potentially, in a smart city context, lear-ners can be to enabled through the appropriate and optimised application and design of pedagogy.

\section{Socio-learning in the smart city (urban) context}

The smart city concept is based on the knowledge and innovation economy approach [5] enabled by the ubiquity of computer technology. The role of technology within a smart city environment is that of a pusher; solutions are elicited through rapid advances in science and technology, whether or not society or economy demands or needs them. The flip side of economy is the source of demand or the pull; solutions are provided in response to the demand created by society or economy. As the 
footprint increases to encompass the smart concept in the form of an agglomeration of connected spaces and attributes, so too does the complexity of the task of understanding the factors affecting the smart economy. The current smart economy is described as a push economy [5] supported by the current research evidence [6].

The ubiquity of technology has created a "noisy" environment experience for all actors, which means that learners and experts alike may be overwhelmed by the increasing abundance [22] of information, data, communication, and tools. The presence of this noise may have a mitigating or seriously detrimental effect on the learning experience depending on the user-technology attribute relationship. The shift towards the technology enabled environment [23] is reflected in the education curricula of schools and universities with a subsequent increase in vendor numbers offering solutions to perceived problems. The search for alternative learning spaces [14] may be associated with a desire to mitigate the effects of the digital noise flooding into the learning environment as a result of the technology push cycle.

Knowledge of the relationship between learners and the smart city environment may be determined through appropriate use of the opportunities offered by the presence of enhanced data gathering, i.e. big data. Lifelong learning is a social event, irrespective of people's age or socio-economic status. Learning does not take place in a vacuum or in a fixed temporal space. Social interaction is required and this fact must be considered within any technology enabled paradigm. Lifelong learning exists in a temporal continuum related to the societal and personal needs of the learner [24]; the mind develops at different times depending on the learner and how the learner has internalized their own experiences. As a direct result, the metacognitive awareness of the learner increases with age [25], leading to their engagement in a self-directed process as adults.

The opportunities presented by the increasing awareness of the metacognitive ability are alluded to in the discourse of lifelong learning in what is considered the fourth industrial revolution [26]. However, they are seen in the light that mostly illuminates the economic values in terms of productivity and value for money; at the same time lifelong learning offers much more than productivity and financial gain. Its alternative benefits may include social, psychological and internalized enhancements for the person and society.

\section{Motivation and belonging: fostering the desire for learning}

Lifelong learning does not take place within the constraints of a single domain of expertise as learners engage with opportunities for social and personal mobility [5]. Technology has been postulated as offering benefits to society as an enabler towards efficiency, sustainability, communication, democracy, education, health, innovation and creativity. The wonder of technology as a "pill for every ill" was discussed in the literature but little attention has been paid to the diversity of culture and society. To accommodate true lifelong learning within a multicultural, connected and integrated smart city environment, the learning paradigm must be cognizant of diversity. A failure to address the needs of diversity will result in a failure to be inclusive and to support the nurturing required by some for an enjoyable and immersive experience.

The socio-cognitive construct of self-efficacy $[27 ; 28]$ is a vital consideration if the behavioural change is to take place. The highly complex context of a smart city may offer many opportunities, but it hides dangers, too. The dangers are in the form of a disadvantage to those learners that would be more commonly described as low achievers, socio-economic disadvantaged, having a learning disability, and the socially disconnected. Lifelong learning is recognised as requiring a certain degree of motivation and resilience to achieve personal goals and these attributes may be derogated in the internalized view of those not considered to be high achievers. It may be observed that the self-efficacy concept within metacognition refers to the learner's knowledge of their own cognitive ability, knowledge of the nature of cognitive tasks, knowledge of the strategies required to cope with such tasks, and the belief the learner has within themselves of being able to complete the task. In addition, the learner requires overarching skills to monitor and regulate their own cognitive activities.

The processes of learning can only be inferred, usually by a domain expert, as evidenced through writing, problem solving, etc., and there must be a definite link to allow the learner to claim that learning has been achieved [29]. The outcome must be judged to be fair - the valence must be considered appropriate [30]. The resulting motivation for the learner in a fair learning environment is critical to the sense of belonging the learner may have. The sense of belonging may 
be in the form of a professional standing, social enjoyment, hobby, re-alignment of beliefs, supporting a desire to participate more fully in the economic activity of the city. The sense of belonging to a particular domain is described in socio-sustainable healthy city project exemplars [31]. Belonging is described through spatial planning, best practice, participation and resilience, infrastructure, nature, people and place as an integrated construct encompassing all actors within the process. Belonging is cognizant of all factors including those considered less harmonious but necessary for further development and growth; belonging is being nurtured through learning.

\section{Inclusion through Open Learning in a technology environment}

If the role of an active learner is to be recognised, then an alternative is required in which the learner is central to active learning and which will use feedback as a facilitating mechanism $[32 ; 33]$. There is a widely spread opinion that learners entering higher education are accomplished self-directed and self-regulated learners, however, this perception $[32$, p. $705 ; 34]$ may be unfounded.

Pedagogy must accommodate the need to realign the learners with the need to identify with the community [21] of active learners. Active learners have a sense of their own learning and educational authorities are expecting that learners would take a greater responsibility for their own learning [35-37]. Markkula and Kune [38] recognise the need for an active learning paradigm to ensure that smart regions continue along the smart trajectory as universities adapt to their changing roles in society and economy. The function of the university is not globally homogeneous; this role has adapted to suit the region. The role of the knowledge exchange platform provider $[38, \mathrm{p} .10]$ is the one that many universities have adopted to, connect, infuse knowledge, provide accessible learning, meet needs of society present and future, and prepare learners for engagement emerging capacity building exercises.

The knowledge platform is prioritized within the 2016 Russian Government project Modern Digital Learning Environment in the Russian Federation with the aim of expanding accessible learning to 11 million people by 2025. Central to the success of this project is the Open Learning platform using the Massively Open Online Course (MOOC) structure. The limitations of many MOOC designs have been recognised [39] by the project investigators and addressed through comprehensive determination of metrics for success in Open Learning.

An example of using MOOCs for inclusion is in smart cities, where MOOCs can perform the role of generating interest in innovative entrepreneurship [40]. The project revealed the need for constant dialogue between all actors in a smart city to ensure inclusion of all stakeholders and flexibility of learning spaces to promote interactivity. Of interest was the fact that the "technology environment" existed but the "smart learners" did not exist at the beginning of the process. The heterogenous nature of society must be accommodated to "close the loop" and engage all actors within the complex hierarchy of the smart city concept. Not all learners respond equally to the stimuli offered by a learning paradigm; the Open Learning technology mediated model has the potential to offer meaningful and inclusive engagement.

\section{Project enabled collaboration in the online learning environment}

Massive open online courses with a strong connectivist component and project-based learning tools have a great potential for involving broad sectors of the population in the processes of smart-city development and creating a comfortable urban environment. The involvement of various population sectors is made possible through Collaborative MOOCs, based on the interaction of all participants in learning by creating new knowledge and solving a common problem [41]. The peculiarity of this type of MOOC is equality of all participants in the learning process: they are all teachers and students at the same time. MOOCs are also characterized by the presence of built-in communication tools such as chats, blogs, wiki, social networks and others.

The project-based methodology has been developed by modern pedagogy in the recent decades $[42 ; 43]$ as a way to enhance the student's intellectual activity and increase their motivation. This methodology offers strong potential for efficacious use of electronic and distance learning [44]. The essence of project training, according to J. Delors [45], is to "learn to learn, learn to do, learn to live together, learn to live", which are the fundamental components of lifelong learning. The methodological basis of project activity is described by J. C. Jones [46], J.-I. Beyk [47], and C. Frey [48], who are trying to overcome the one- 
side pragmatic interpretation of the process and results of the project and achieve a more humanistic understanding of the project as an activity component of learning aimed at developing the personality of a learner.

Implementation of the project method in online learning is not an easy task due to the lack of communication between the participants in the asynchronous online learning format. The student should have a certain level of preparedness and motivation for this type of activity. In addition, the introduction of project-based training requires a special pedagogical design of such online courses as well as support for students throughout the learning process. It is especially important to make it possible for students to solve the tasks step by step and to find adequate forms of testing learning outcomes [49]. Project results should be achievable and solutions should be optimal. The project should thus create conditions for students' acquisition of the necessary knowledge and skills and for their practical application, improvement and consolidation.

The Ural Federal University (Ekaterinburg, Russia) has considerable experience of involving high school seniors and college graduates in online project activities within the framework of the "Internet Test Drive" campaign, which was aimed at finding talented applicants and preparing them for study at the university. Thus, the university's experience provides a series of exemplars for the project learning methodology. In 2015-16, more than 500 young people were offered a choice of several real projects in various educational fields as a part of the programme of project-based collaborative learning:

1. The aim of the socio-cultural project Cult Drive was to design a publishing product to attract public attention to the cultural and historical heritage of the city, demonstrating the values and characteristics of regional culture.

2. Engineering and technical project TechDrive was aimed at developing, preparing for production and launching a new product on the market. The project was based on the theory of inventive problem solving and used the corresponding methodology and tools.

3. The project in the field of robotics Hi-TechDrive offered its participants an opportunity to develop a real robotic complex, its 3D model, electronic circuitry and a program for autonomous control of the air-based robot Ardron (unmanned copter).
4. The development project Stroy-InvestDrive included conceptualization, creation of a 3D model and assessment of the effectiveness of investment in the construction of a socially significant real estate object for a region, city, or village with an emphasis on "green" technologies.

5. The project in the field of information technologies Mobile-Drive offered its participants an opportunity to create a real mobile application for smartphones on one of the three mobile platforms: iOS, Android or Windows Phone.

6. The natural science project Nature - Drive offered an exciting quest about the laws of nature.

7. The informational and technical project $W E B$-Drive involved students in the process of creating a real WEB-application (website) in a high-level language: from deploying the development environment to posting the resulting application on the Internet.

8. The socio-economic project $H R$ - Drive was aimed at creating a business (start-up project), with a group of participants working towards a common goal - generating income from commercial activities.

All projects were designed to produce an authentic experience of problem solving and be as close as possible to real professional activities in each area. The results had a practical significance for the community. The participants were divided into teams of 6-8 people and worked on projects remotely through an electronic information and communication environment, using built-in and external interaction services. During their training, students mastered MOOCs, passed learning outcomes assessments and took part in webinars, where practical issues and problems arising during the project implementation were discussed. The results were presented at the final defence of the projects, which involved teachers and experts.

The potential exists for appropriate scaling of the authentic problems and for them to be used as a mechanism for involving wide sections of the population. The collaborative involvement of various groups of people as a community of active participants offers considerable potential for enhancement of urban learning development processes.

\section{Exploration of learning in technology enabled smart/modern cities}

Rhetoric on the smart city vision is bounded mainly within two discourses: the marketing material of large IT companies and academic liter- 
ature [50]. Both discourses place the lens firmly on technology as a normative component of the modern city and the co-presence of the citizen is relegated to that of a partially informed bystander. In line with the definition by Kominos [7] and the driving technology economic push $[5 ; 6]$, the smart city concept has been explored in Ireland and expanded to include the concept of the smart region.

Smart city projects are operating in the Republic of Ireland (Dublin, Limerick, Galway, Waterford and Cork) and in Northern Ireland (Belfast and Derry). The forum connecting smart cities is located in Maynooth University and enables them to share insights, experiences and promote collaborative research. The transnational networked group of smart cities operates on the basis of a national and local-level epistemic community [51].

Critique of the literature of the smart city projects in Ireland reveals little substance relating to the participation of the citizen [52]. The goals of the smart city projects (to stimulate economic activity, address regional challenges, optimize sustainable actions, and enhance SME competitiveness) are to be achieved with the help of industry or universities. Concepts of co-creation, partnership, and citizen-led agency are not highlighted, rather, they are placated by token consultations and paternalistic actions by experts and civic leaders. Kitchin et al [51] identify these issues as the "last mile problem". The programmes of research and implementation are met with increasing apathy by the staff involved in the projects. There is also considerable inertia and internal resistance in what concerns governance, policy implementation and support for technology driven activities. It is reasonable to suggest that many technological solutions are proffered regardless of social need or historical context. The role of the epistemic community may be viewed with suspicion when attempting to provide a solution to a multifaceted and highly complex urban problem. Within the epistemic community it may be very difficult to determine the role or voice of the human community within the "city problem" [51].

An expanded form of the smart city concept is the smart region as it aims to address the needs of the regional economy supported by the EU regional policy [53]. The region explored within this project consists of the sparsely populated counties of Western Ireland and those forming the border with Northern Ireland. Using the characteristics defined by Markkula [38], the Smart Places Re- gion [53, p. 569] project is under way as an initiative driven by the Northern and Western Regional Assembly, the Western Development Commission and the Insight Centre for Data Analytics at the National University of Ireland, Galway. The region is serviced by a single university and three institutes of technology in Galway, Sligo and Letterkenny, however, changes in the higher education landscape in Ireland have led to political pressure to merge several institutes of technology to form a technical university.

In response to the online survey conducted for the Smart Places Region, the most popular priority identified by respondents was the smart community. This response supports the critique of the smart concept by Cardullo and Kitchin [52], who conclude that significant effort is required to ensure that citizens are seen within the spotlight of "smart" and that "smart citizenship" becomes the norm.

In parallel with the smart initiatives under way in Ireland, Borkowska and Osborne [54], it is interesting to examine the role of inclusion within the British smart city of Glasgow by using the quadruple helix model. In this model, citizens are seen as active users of the city, they are central players within the decision-making processes and technology is evaluated in order to ensure that it meets the needs of citizens and society. Learning provides a foundation on which the inclusion of citizens is to be built and the concept of smart city is now expanded to include a learning framework. Tensions within the smart city concepts are prevalent in the discourse of smart cities in Ireland, which was pointed out by Kitchen et al [51]. The same applies to Glasgow: citizen engagement at all levels is uncommon and the infrastructure for learning is not fully provided for; the technology should not be "pushing" education and learning.

Community-based learning, whether it be individual, group, community, or industrial, has the potential to tap into citizenship in its truest sense by involving all citizens and not merely those considered to be epistemologically strong in the digital sense.

\section{Conclusion}

The hegemony of technology enhanced learning is increasingly difficult to ignore or resist in pedagogical design of modern learning paradigms; its ubiquity is undoubtable. The social logics of technology enhanced learning and the alliances formed around it are such that its incorporation into the fabric of society is expected. The hetero- 
geneous nature of learning and lifelong learning is such that designers must remain cognizant of the complex interactive nature of the actors, tensions and affordances of technology enhanced learning. Re-imagining the pedagogical paradigms to maintain alignment with the needs of society in association with the hegemonic nature of technology enhanced learning is an increasingly difficult problem. The pedagogical paradigms must not lose sight of the fact that in the face of technological dominance, the ultimate goal is satisfaction of the needs of society members.

The role of technology enhanced learning as an enabler for lifelong learning is beyond doubt in the modern-smart city and beyond. The connectivist nature of the technology is demonstrated in the presence of Open Learning paradigms, whether used in traditionally designed modes of learning or in expansive and creative community-based modes. The technology is capable of serving social, educational and economic systems.
Research is required to consider the nuances of lifelong learning enabled by technology and address the gaps in the learning paradigm. The exemplars of collaborative learning experiences enabled by technology enhanced learning delivered through project-based pedagogies suggest that true interactive and vicarious learning can occur. Further exploration of the nature of collaboration should be encouraged to establish the best practice for social inclusion of those less motivated to enable them to participate more fully in society.

It may be some time before the stakeholders and actors in smart cities, smart regions, and smart economies fully address the recommendations by UNESCO [55] for Adult Learning and Education. The role of lifelong learning in adult learning in its many guises is essential to allow people to engage and participate fully in society. It is an imperative that the technocrats do not encumber the role of the citizen.

\section{References}

1. Andone, D., Holotescu, C., \& Grosseck, G. (2014). Learning Communities in Smart Cities. Case Studies. In 2014 International Conference on Web and Open Access to Learning (ICWOAL), 25-27 Nov. 2014. Dubai: United Arab Emirates, IEEE. doi: 10.1109/ICWOAL.2014.7009244

2. Giffinger, R. et al. (2007). Smart Cities: Ranking of European Medium-Sized Cities. Centre of Regional Science, Vienna UT. Retrieved from http://www.smart-cities.eu/download/smart cities final report.pdf

3. Albino, V., Berardi, U., \& Dangelico, R. M. (2015). Smart Cities: Definitions, Dimensions, Performance, and Initiatives. Journal of Urban Technology, 22(1), 3-21. doi: 10.1080/10630732.2014.942092

4. Turcu, C. (2013). Re-thinking Sustainability Indicators: Local Perspectives of Urban Sustainability. Journal of Environmental Planning and Management, 56(5), 695-719. doi: $\underline{10.1080 / 09640568.2012 .698984}$

5. Angelidou, M. (2015). Smart Cities: A Conjuncture of Four Forces. Cities, 47, 95-106. doi: 10.1016/j.cities.2015.05.004

6. Anthopoulos, L. G. (2015). Understanding the Smart City Domain: a Literature Review. In M. P. Rodríguez-Bolívar (Ed.), Transforming City Governments for Successful Smart Cities (pp. 9-21). Cham: Springer International Publishing. doi: 10.1007/978-3-319-03167-5 2

7. Gianni, F., \& Divitini, M. (2015). Technology-Enhanced Smart City Learning: a Systematic Mapping of the Literature. Interaction Design and Architecture(s) Journal, 27, 28-43.

8. Hammad, R., \& Ludlow, D. (2016). Towards a Smart Learning Environment for Smart City Governance. In Proceedings of the $9^{\text {th }}$ International Conference on Utility and Cloud ComputingUCC '16 (pp. 185-190). Shanghai, China: ACM Press. doi: $\underline{10.1145 / 2996890.3007859}$

9. Goodchild, T., \& Speed, E. (2018). Technology Enhanced Learning as Transformative Innovation: a Note on the Enduring Myth of TEL. Teaching in Higher Education. doi: $\underline{10.1080 / 13562517.2018 .1518900}$

10. Skinner, B. F. (1965). Review Lecture: the Technology of Teaching. Proceedings of the Royal Society of London. Series B. Biological Sciences, 162(989), 427-443. doi: 10.1098/rspb.1965.0048

11. Shannon, C., \& Weaver, W. (1964). The Mathematical Theory of Communication. The University of Illinois Press, Urbana. 
12. Traxler, J. (2018). Learning with Mobiles: The Global South. Research in Comparative and International Education, 13(1), 152-175. doi: 10.1177/1745499918761509

13. Brown, K., \& Lally, V. (2017). Myths, Rhetoric and Opportunities Surrounding New Teaching Technologies: Engineering Mathematics Education. In EDCRUNCH Ural: New Educational Technologies at the University: Proceedings of the International Scientific and Methodological Conference. 25-27 Apr. 2017 (pp. 2-10). Ekaterinburg: Ural Federal University. Retrieved from http://elar.urfu. ru/bitstream/10995/54249/1/notv 2017 01.pdf

14. Marshalsey, L., \& Sclater, M. (2018). Critical Perspectives of Technology-Enhanced Learning in Relation to Specialist Communication Design Studio Education within the UK and Australia. Research in Comparative and International Education, 13(1), 92-116. doi: $\underline{10.1177 / 1745499918761706}$

15. Lally, V., Sclater, M., \& Brown, K. (2018). Technologies, Learning and Culture: Some Emerging Themes. Research in Comparative and International Education, 13(1), 227-235. doi: $\underline{10.1177 / 1745499918770951}$

16. Bystrova, T. Yu., Larionova, V. A., Osborne, M., \& Platonov, A. M. (2015). Introduction of Open E-Learning System as a Factor of Regional Development. R-Economy, 1(4), 587-596. doi: 10.15826/recon.2015.4.021

17. Fischer, G. (2014). Beyond Hype and Underestimation: Identifying Research Challenges for the Future of MOOCs. Distance Education, 35(2), 149-158. doi: 10.1080/01587919.2014.920752

18. Czerniewicz, L. (2018). Inequality as Higher Education Goes Online. In B. N. Dohn, S. Cranmer, J.-A. Sime, M. de Laat, \& Th. Ryberg (Eds), Networked Learning: Reflections and Challenges (pp. 95-106). Springer, Cham. doi: 10.1007/978-3-319-74857-3 6

19. Liyanagunawardena, T. R., Williams, S. A., \& Adams, A. A. (2013). The Impact and Reach of MOOCs: a Developing Countries' Perspective. eLearning Papers, 38-46. Retrieved from http:// centaur.reading.ac.uk/38250/

20. Honeychurch, S., \& Patrick, F. (2018). Massive Open Online Courses as Affinity Spaces for Connected Learning: Exploring Effective Learning Interactions in One Massive Online Community. Research in Comparative and International Education, 13(1), 117-134. doi: 10.1177/1745499918768112

21. Wenger, E. (1998). Communities of Practice: Learning, Meaning and Identity. Cambridge, UK: Cambridge University Press.

22. Quinlan, O. (2017). Changes to Academic Practice in the Twenty-First Century. In N. Kucirkova, \& O. Quinlan (Eds), The Digitally Agile Researcher (pp. 1-11). London, UK: Open University Press.

23. Redecker, C., \& Johannessen, O. (2013). Changing Assessment - Towards a New Assessment Paradigm Using ICT. European Journal of Education, 48(1), 79-96. doi: 10.1111/ejed.12018

24. Flavell, J. H. (2004). Theory-of-Mind Development: Retrospect and Prospect. Merrill-Palmer Quarterly, 50(3), 274-290. doi: 10.1353/mpq.2004.0018

25. Lockl, K., \& Schneider, W. (2006). Precursors of Metamemory in Young Children: the Role of Theory of Mind and Metacognitive Vocabulary. Metacognition and Learning, 1(1), 15-31. doi: 10.1007/s11409-006-6585-9

26. Schwab, K. (2015, December 12). The Fourth Industrial Revolution: what it means and how to respond. Foreign Affairs. Retrieved from https://www.foreignaffairs.com/articles/2015-12-12/ fourth-industrial-revolution

27. Bandura, A. (1977). Self-Efficacy: Toward a Unifying Theory of Behavioral Change. Psychological Review, 84(2), 191-215. doi: 10.1037/0033-295X.84.2.191

28. Artino, A. R. (2012). Academic Self-Efficacy: from Educational Theory to Instructional Practice. Perspectives on Medical Education, 1(2), 76-85. doi: 10.1007/s40037-012-0012-5

29. Dearden, R. F. (1979). The Assessment of Learning. British Journal of Educational Studies, 27(2), 111-124. doi: $10.1080 / 00071005.1979 .9973540$

30. Vroom, V. H., \& Deci, E. L. (1992). Management and Motivation ( $2^{\text {nd }}$ ed.). London, UK: Penguin Group. 
31. Azeiteiro, U. M., Akerman, M., Leal Filho, W., Setti, A. F. F., \& Brandli, L. L. (Eds.) (2018). Lifelong Learning and Education in Healthy and Sustainable Cities. Springer, Cham. doi: 10.1007/9783-319-69474-0

32. Boud, D., \& Molloy, E. (2013). Rethinking Models of Feedback for Learning: the Challenge of Design. Assessment \& Evaluation in Higher Education, 38(6), 698-712. doi: 10.1080/02602938.2012.691462

33. Narciss, S., Sosnovsky, S., Schnaubert, L., Andrès, E., Eichelmann, A., Goguadze, G., \& Melis, E. (2014). Exploring Feedback and Student Characteristics Relevant for Personalizing Feedback Strategies. Computers \& Education, 71, 56-76. doi: 10.1016/j.compedu.2013.09.011

34. Brown, K., \& Lally, V. (2018). Rhetorical Relationships with Students: A Higher Education Case Study of Perceptions of Online Assessment in Mathematics. Research in Comparative and International Education, 13(1), 7-26. doi: 10.1177/1745499918761938

35. Pachler, N., Daly, C., Mor, Y., \& Mellar, H. (2010). Formative e-Assessment: Practitioner Cases. Computers \& Education, 54(3), 715-721. doi: 10.1016/j.compedu.2009.09.032

36. Wang, T.-H. (2010). Web-Based Dynamic Assessment: Taking Assessment as Teaching and Learning Strategy for Improving Students e-Learning Effectiveness. Computers \& Education, 54(4), 1157-1166. doi: $10.1016 /$ j.compedu.2009.11.001

37. Gikandi, J. W., Morrow, D., \& Davis, N. E. (2011). Online Formative Assessment in Higher Education: A Review of the Literature. Computers \& Education, 57(4), 2333-2351. doi: 10.1016/j. compedu.2011.06.004

38. Markkula, M., \& Kune, H. (2015). Making Smart Regions Smarter: Smart Specialization and the Role of Universities in Regional Innovation Ecosystems. Technology Innovation Management Review, 5(10), 7-15. doi: 10.22215/timreview/932

39. Fischer, G. (2014). Beyond Hype and Underestimation: Identifying Research Challenges for the Future of MOOCs. Distance Education, 35(2), 149-158. doi: 10.1080/01587919.2014.920752

40. Holotescu, C., Slavici, T., Cismariu, L., Gotiu, L. O. L., Grossek, G., \& Andone, D. (2016). MOOCs for Innovative Entrepreneurship in Smart Cities. World Journal on Educational Technology, 8(3), 245-251. doi: 10.18844/wjet.v8i3.832

41. Yeager, C., Hurley-Dasguptaand B., \& Bliss, C.A. (2013) cMOOCs and Global Learning: an Authentic Alternative. Journal of Asynchronous Learning Networks, 17(2), 133-147. Retrieved from https://www.learntechlib.org/p/154153/

42. Vygotskij, L. S. (1996). Pedagogical psychology. Moscow: Pedagogika-Press. (In Russ.)

43. Genisaretskiy, O. I. (2010). Design Culture and Conceptualism. Retrieved from http://gtmarket.ru/laboratory/expertize/2006/2682 (In Russ.)

44. Drysdale, J. J., Graham, Ch. R., \& Borup, J. (2014). An Online High School «Shepherding» Program: Teacher Roles and Experiences Mentoring Online Students. Journal of Technology and Teacher Education, 22(1), 9-32.

45. Delors, J. (1996). Learning: The Treasure within. Report to UNESCO of the International Commission on Education for the Twenty-First-Century. Paris: UNESCO.

46. Jones, J. Ch. (1970) Design Methods: Seeds of Human Futures. Wiley, UK.

47. Bake, J.-I. (2010). The Project Method (Die Projektmethode). Theory and Practise. Seminer paper. GRIN-Verlag.

48. Frey, K. (1997). Die Projektmethode. Berlin: Baeltz.

49. Black, P., \& Wiliam, D. (2009). Developing the Theory of Formative Assessment. Educational Assessment, Evaluation and Accountability, 21(1), 5-31. doi: 10.1007/s11092-008-9068-5

50. Thomas, V., Wang, D., Mullagh, L. \& Dunn, N. (2016). Where's Wally? In Search of Citizen Perspectives on the Smart City. Sustainability, 8(3), 207. doi: 10.3390/su8030207

51. Kitchin, R., Coletta, C., Evans, L., Heaphy, L., \& Mac Donncha, D. (2017). Smart Cities, Urban Technocrats, Epistemic Communities and Advocacy Coalitions. The Programmable City Working Paper 26. doi: 10.31235/osf.io/rxk4r 
52. Cardullo, P., \& Kitchin, R. (2018). Being a "Citizen" in the Smart City: Up and Down the Scaffold of Smart Citizen Participation in Dublin, Ireland. GeoJournal, 1-13. doi: 10.1007/s10708018-9845-8

53. O’Brolchain, N., Ojo, A., Porwol, L., Minton, D., \& Barry, C. (2018). Examining the Feasibility of a Smart Region Approach in the North West Atlantic and Borders Region of Ireland. In Proceedings of the $11^{\text {th }}$ International Conference on Theory and Practice of Electronic Governance, April 4-6, 2018 (pp. 568-574). Galway, Ireland. doi: 10.1145/3209415.3209512

54. Borkowska, K., \& Osborne, M. (2018). Locating the Fourth Helix: Rethinking the Role of Civil Society in Developing Smart Learning Cities. International Review of Education, 64(3), 355-372. doi: $10.1007 /$ s11159-018-9723-0

55. UNESCO Recommendation. (2015, October 22). Retrieved from http://uil.unesco.org/ adult-education/unesco-recommendation

\section{Information about the authors}

Ken Brown - Masters in Control Systems and e-Learning, Lecturer in School of Engineering, Letterkenny Institute of Technology (Port Road, Letterkenny, Co Donegal, F92 FC93, Ireland); e-mail: ken.brown@lyit.ie.

Viola A. Larionova - PhD in Physical and Mathematical Sciences, the Director of the Research and Education Center "Open Education", Associate Professor, Head of Academic Department of Economics and Management in Construction and Real Estate Development of the Graduate School of Economics and Management, Ural Federal University (19 Mira St., 620002, Ekaterinburg, Russia); e-mail: viola-larionova@yandex.ru.

Vic Lally - Professor of Education in the School of Education, University of Glasgow (Glasgow, G12 8QQ, Scotland, UK); e-mail: vic@viclally.co.uk. 